\title{
Green Infrastructure Incentives to Mitigate Flooding in Madison, WI
}

\section{Sarah Alexander ${ }^{1}$, Laura Borth ${ }^{2}$, Jennifer Bratburd ${ }^{3}$, Marie Fiori ${ }^{4}$}

${ }^{1}$ University of Wisconsin-Madison, Department of Civil and Environmental Engineering, Madison, WI

2University of Wisconsin-Madison, Department of Nutritional Sciences, Madison, WI

${ }^{3}$ University of Wisconsin-Madison, Department of Bacteriology, Madison, WI

${ }^{4}$ University of Wisconsin-Madison, Department of Chemistry, Madison, WI

http://doi.org/10.38126/ISPG170201

Corresponding author: salexander6@wisc.edu

Keywords: Wisconsin; green infrastructure; flooding; urban development

Executive Summary: Extreme flooding events are increasingly common due to climate change and the City of Madison, Wisconsin is uniquely at risk. The City can mitigate further flood damage by encouraging development of green infrastructure. We recommend the City incentivize green infrastructure by creating a small grants program for residential green infrastructure projects, modeled after a successful program in Milwaukee and funded by pairing federal grants with an increase in the water rate structure. The grant program could be supplemented by altering the City's stormwater fees to shift cost to residents generating the most runoff and by a volunteer program that would engage community members.

\section{Statement of issue}

Globally, climate change has led to an increase in extreme weather events, and Madison is no exception (U.S. Global Change Research Program 2014). Despite recent improvements, Madison remains uniquely prone to flooding since the major commercial center of the city stretches across a narrow isthmus. Commercial and residential development replaced natural wetlands (ecosystems that naturally mitigate floods) with impervious surfaces that facilitate water run-off. For decades, Madison politicians and residents have argued about how to manage the lakes and best mitigate flood risk. In August 2018, the city experienced a 100-year flood event that caused damages of more than $\$ 154$ million across Dane County (Novak 2018). Despite investments over the last few decades to improve the storm sewer system, current infrastructure did not protect the city during this 100-year flood event (City of Madison 2012). Given predictions of increased extreme rainfall and flood events as the climate changes, compounded by continued development reducing natural infiltration, Madison needs to implement additional strategies to mitigate flood risk (U.S. Global Change Research Program 2014).

\section{Introduction}

Green infrastructure strategies improve water management while increasing aesthetics and community enjoyment. The goals of green infrastructure are twofold: 1) to capture excess water from extreme rainfall events for reuse (e.g. using rain barrels) and 2) to reduce the amount of hard, impervious surface and allow excess water to infiltrate into the soil (e.g. through green roofs, porous pavement, native landscaping, rain gardens, stormwater trees, and greenways). Capturing water and reducing runoff help control water quantity (amount of runoff) and improve water quality (by filtering out contaminants). Both are critical for managing extreme rainfall and decreasing flood risk. Additionally, installation of green infrastructure benefits the community by increasing urban habitat for native pollinators, increasing biodiversity, and adding community green space (City of Milwaukee Green Infrastructure Plan 2019). 
Implementation of green infrastructure has proven to be economically and environmentally advantageous in similar locations (i.e. located directly along water bodies with heightened flood risk). Milwaukee recently amended their regional green infrastructure plan to store 36 million gallons of stormwater and add 143 acres of green space by 2030 (City of Milwaukee Green Infrastructure Plan 2019). In developing the plan, Milwaukee Metropolitan Sewage District (MMSD) found that their improvements would recharge up to 4 billion gallons of groundwater per year and save 16,500 megawatt-hours per year (equating to a cost savings of $\$ 1.5$ to $\$ 2.1$ million). Further, it will reduce emissions, leading to improved health worth $\$ 9.1$ million in annual health care savings (MMSD 2013).

\section{Current policy and legal practice in Madison}

Both Madison's urban environment and the artificially raised water level of Lake Mendota worsened the 100-year flood event in Madison (Wright 2018). In fact, the August 2018 flood resulted from a rainstorm predicted to occur every 20-50 years.

Lake Mendota is currently five feet higher than natural levels, which greatly increases the risk that additional rains will overwhelm Tenney Lock's ability to regulate levels (Fenneman 1910, 42). Flash floods due to rising lake levels are most likely to occur on the East and South sides of the city (City of Madison Engineering 2019). Many of Madison's Black and Latino residents live in these neighborhoods, so it is essential that the City take steps to prevent future floods in order to be consistent with Madison's Racial Equity \& Social Justice Initiative (Blank 2016; City of Madison n.d.).

Conservationists believe that the water in Lake Mendota should be lowered to mitigate flooding. Most proposals suggest lowering the lake level by 12 feet which would expose large amounts of wetlands (Arthur 2019; Mesch 2019). Though these wetlands would greatly improve Madison's flood resilience, homeowners on the lake oppose this change. Lowering the lakes would change the shoreline, making it necessary to extend boat piers and repair boats damaged in shallower water. Recently, some local experts argue that controlling lake levels alone is not enough to prevent flooding (Cieslewicz 2018; Verberg 2018).

The contentious discussions and political challenges surrounding the efficacy of lowering lake levels suggest alternative efforts are needed to mitigate future floods in Madison as extreme rainfall and flooding are projected to become more frequent (U.S. Global Change Research Program 2014). Wisconsin law prohibits municipalities from implementing stronger stormwater regulations for developers than existing state ordinances (Wisconsin State Legislature 2018). Therefore, Madison should develop incentive programs to improve the flood resistance of existing properties. Madison is the fastest growing city in Wisconsin, so reducing development in established neighborhoods is not an option (Hubbuch 2019). Green infrastructure provides the opportunity to install flood mitigation techniques around existing buildings as an integral part of the city, allowing Madison to adapt to the changing climate without imposing stringent and possibly economically detrimental green regulations on new development. A recent green infrastructure pilot study (605 homes, city reimburses $80-100 \%$ of cost) aims to quantify the benefit of stormwater reduction efforts on the watershed, yet further action is needed.

\section{Policy options}

i. Option 1: Execute a grant program to install rain gardens, native plants, and rain barrels

The City of Madison should offer grants to homeowners to cover the installation costs of green infrastructure elements at their properties, reducing the purchase cost for homeowners. Various federal grant programs are available to local governments to incentivize improving water quality and to support programs in line with community priorities, including the Environmental Protection Agency (EPA) Nonpoint source pollution 319 grant program or the EPA urban waters small grants (Environmental Protection Agency 2020a,b). As the EPA outlines, long-term maintenance is essential for realizing the wealth of benefits from green infrastructure (e.g. environmental, social, economic) (Environmental Protection Agency 2018). The EPA also highlights establishing written contracts or procedures as one crucial way to assure continued maintenance. Thus, to ensure that Madison fully benefits from green 
infrastructure projects funded through the program, the City should require recipients to sign a contract promising 20 years of maintenance. The contract should clearly outline the responsibilities (i.e. routine landscape maintenance, removing trash/debris, and cleaning out accumulated sediment) as well as the consequences for non-compliance (e.g. necessary repayment of the funds to the grant program). The contract should also allow for transfer of maintenance responsibilities if home ownership changes.

\section{Advantages}

In neighboring Milwaukee, providing residents with the resources to purchase necessary supplies for green infrastructure implementation may encourage participation (City of Milwaukee Green Infrastructure Plan 2019). Grant programs are a less permanent change to the City's financial structure than a tax incentive, giving the City of Madison the flexibility to alter these programs over time as its needs evolve (i.e. adjust cost payout structure, timing, types of projects included, etc.). These programs have been widely implemented by other cities of similar size and location to Madison, giving the City a blueprint to jumpstart implementation.

\section{Disadvantages}

The City of Madison would need to secure and/or allocate monetary resources at the time of program implementation, which may or may not be feasible. While program flexibility is a clear advantage, a grant program may be easier to disband, potentially lessening the longevity of cumulative benefit.

\section{ii. Option 2: Revising the City of Madison's stormwater fees}

Stormwater taxes are considered a fair and equitable method for directing the cost of green infrastructure towards those who generate the most runoff and benefit the most from improvements (EPA, 2008). Residential and commercial properties currently receive a monthly utility tax, either a flat rate or based on water usage. However, taxes could be modified by the percent impervious surface, shifting the cost onto those who generate the most runoff. The increased monthly fee (and subsequent credit) must be high enough to encourage owners to reduce impervious surfaces. Since stormwater fees already exist in Madison, adding green infrastructure guidelines to the current Rate Adjustment Policy for the Storm
Water Utility requires action only from the Madison Common Council and the City Engineer. The City Engineer can annually adjust the stormwater charges in accordance with Wis. Stats $\S 66.0821(4)$ and the Madison General Ordinance $\mathrm{Ch} 20$ and 37. Minneapolis (Stormwater credit program) and New York (Green roof tax abatement program) have successfully implemented these changes.

\section{Advantages}

The cost of implementation is low; the decreased stormwater tax revenue (i.e. after owners make green infrastructure changes) will be lower than the cost of credits. Further, residents who perform improvements will save money. Implementation could happen quickly, as fees are under the authority of Madison; no public input or voting is required.

\section{Disadvantages}

This structure places the burden of cost and motivation on the resident, as they must front the initial capital, perform improvements, and successfully apply for stormwater credit. This process disproportionately excludes Madison's lowincome residents from participating. Creating unnecessarily complicated credit applications could discourage applicants, possibly requiring a streamlined application or free assistance to encourage use.

iii. Option 3: Implement a volunteer program to support green infrastructure development

Starting a volunteer program to directly engage residents to learn about green infrastructure and to mitigate climate change in their local area will promote community stewardship. Volunteers will participate in a program to acquire background knowledge and hands-on training to earn certification. Afterwards, they will complete yearly community service hours to advocate and assist in the implementation of community clean water projects.

\section{Advantages}

Leveraging social networks and personal connections is a proven strategy for altering social norms within a neighborhood or community, and sparks change in environmental behaviors (McKenzie-Mohr 2011). Volunteer programs have a proven record of facilitating implementation of green infrastructure and developing a network of community 
sustainability leaders (e.g. Master Water Stewards program in Minnesota; Minnehaha Creek Watershed District 2019). Thus, creating a network of informed volunteers to serve as community advocates and to assist residents in implementing green infrastructure projects is a low-cost option.

\section{Disadvantages}

No monetary support is provided to volunteers. Lack of compensation may alter the spatial distribution of projects, especially in lower income areas. Although this option reduces direct cost to the City, volunteer programs would likely require more coordination to implement compared to monetary incentive programs.

\section{Policy recommendation}

We recommend that the City of Madison prioritize development of a grant program to incentivize the implementation of green infrastructure projects on residential properties. Up-front monetary allocations have the clear advantage of assisting residents with capital costs at the time of incurrence (proven to be more impactful and sustainable). Given the vulnerability of the isthmus and lower-income areas in south and east Madison to climate changes, and flooding in particular, we suggest that the City structure this green infrastructure program to provide more incentives to vulnerable areas (i.e. higher grants and rebates to lower-income multi-unit developments and residential properties in floodprone neighborhoods).

To address possible disadvantages of funding and program longevity, we suggest that the City initially fund the grant and rebate program by applying for federal funds that support water quality and climate resilience. Long-term, the program could be financed by a slight increase to the water rate structure, effectively distributing the cost of mitigating climate change impacts among residents. Voluntary participation should be available for residents who do not require monetary funding to implement green infrastructure projects yet wish to take part.

As climate change results in increased heavy precipitation events in the Madison area, the City must plan and prepare to mitigate negative impact. We recommend that the City also consider revising stormwater fees and partner with local non-profits, such as Clean Lakes Alliance, to implement a volunteer program that will engage residents. Given the vulnerability of the isthmus and high percentage of residential properties in the city, actionable steps to incentivize residential green infrastructure projects are critical for climate adaptation.

\section{References}

Arthur, Keely. 2019. "Dane County looks into permanently lowering Lake Mendota." Channel3000, December 20.https://www.channel3000.com/danecounty-looks-into-permanently-lowering-lakemendota/

Blank, Lew. 2016. "The shocking racial gap of Madison WI." Fascination Hub, February 28.

https://fascinationhub.wordpress.com/2016/02 28/the-shocking-racial-gap-of-madison-wi/

Cieslewicz, Dave. 2018. "Just reducing lake levels won't prevent flooding. We need to do more." Isthmus, November 29. https://isthmus.com/news/coverstory/reducing-madison-lake-levels-will-notprevent-flooding/

City of Madison. n.d. "Racial Equity \& Social Justice Initiative", Civil Rights. Accessed April 1, 2020. https://www.cityofmadison.com/civilrights/programs/racial-equity-social-justiceinitiative

City of Madison. Common Council. 2012. CHAPTER 37 THE PUBLIC STORMWATER SYSTEM INCLUDING EROSION CONTROL 2012. CODE OF ORDINANCES CITY OF MADISON VOLUME IV CHAPTERS 32-45 https://library.municode.com/wi/madison/code s/code of ordinances?nodeId=COORMAWIVOIVC H32--45 CH37THPUSTSYINERCO

City of Madison Engineering. 2019. "High Lake Level Flooding." October 7.

https://storymaps.arcgis.com/stories/b0be9f1c8 7674acaa6951fd9271ad606

City of Milwaukee Green Infrastructure Plan. 2019. Accessed March 1, 2020.

https://city.milwaukee.gov/ImageLibrary/WCC/ Images/GreenLots/FINALGIPLAN--reduced 2.pdf Program for States and Territories." Accessed March 1, 2020. https://www.epa.gov/nps/319grant-program-states-and-territories.

Environmental Protection Agency. 2020b. "Urban Waters Small Grants.” Accessed March 1, 2020. https://www.epa.gov/urbanwaters/urbanwaters-small-grants.

Environmental Protection Agency, 2008. Managing Wet Weather with Green Infrastructure Municipal Handbook: Funding options. Accessed March 1, 2020. https://www.epa.gov/green-
Environmental Protection Agency. 2020a. "319 Grant 
infrastructure/green-infrastructure-municipalhandbook

Fenneman, N. M. 1910. Wisconsin Geological and Historical Survey. Bulletin No. VIII: On the Lakes of Southeastern Wisconsin. Madison: State of Wisconsin. https://books.google.com/books?id=AiQ1AQAA MAAJ\&printsec $=$ frontcover $\# v=$ onepage $\& q \& f=$ fals e

Hubbuch, Chris. 2019. "Census: Madison, suburbs top list of fastest-growing cities in Wisconsin." Wisconsin State Journal, May 23.

https://madison.com/wsj/news/local/govt-andpolitics/census-madison-suburbs-top-list-offastest-growing-cities-in/article c079b92b-1f185ac4-8538-0c74e004e018.html

McKenzie-Mohr, Doug. Fostering Sustainable Behavior: An Introduction to Community-Based Social Marketing. Victoria: New Society Publishers, 2011.

Mesch, Shelley K. 2019. "CRANES environmental group says Dane County should lower Lake Mendota level." Wisconsin State Journal, April 5. https://madison.com/wsj/news/local/govt-andpolitics/cranes-environmental-group-says-danecounty-should-lower-lakemendota/article a7068838-f799-5782-919dfa523b7cd913.html

Milwaukee Metropolitan Sewerage District. 2013. Green Infrastructure Plan. Accessed March 1, 2020. https://www.mmsd.com/what-we-do/greeninfrastructure/resources/regional-greeninfrastructure-plan

Minnehaha Creek Watershed District. 2019. "Master Water Stewards." Accessed March 1, 2020. https://www.minnehahacreek.org/getinvolved/volunteer-your-time/master-water$\underline{\text { stewards }}$

Novak, Bill. 2018. "Flood damage exceeds \$154 million in Dane County, officials say." Wisconsin State
Journal, September 5.

https://madison.com/wsj/weather/flooddamage-exceeds-million-in-dane-county-officialssay/article 0635e674-c057-57a0-a888fe2983367b76.html

Environmental Protection Agency. 2018. "Operation and Maintenance Considerations for Green Infrastructure." Accessed March 31, 2020. https://www.epa.gov/G3/operation-andmaintenance-considerations-greeninfrastructure.

U.S. Global Change Research Program. 2014. "National Climate Assessment." Accessed March 1, 2020. https://nca2014.globalchange.gov/report/region s/midwest.

Verburg, Steven. 2018. "Impatience surfaces over slow search for ways to prevent the next flood." Wisconsin State Journal, September 16. https://madison.com/wsj/news/local/govt-andpolitics/impatience-surfaces-over-slow-searchfor-ways-to-prevent-the/article f1db97e4-41635c54-bc49-e31d0a8751eb.html

Wisconsin State Legislature. Assembly. 2018. 2017 WISCONSIN ACT 243.

https://docs.legis.wisconsin.gov/2017/related/a cts/243

Wright, Daniel. 2018. "What Could Happen The Next Time Madison Gets Hit By Extreme Rainfall." WisContext, October 2. https://www.wiscontext.org/what-couldhappen-next-time-madison-gets-hit-extremerainfall

Sarah Alexander is a Ph.D. candidate in the Water Systems and Society Lab at the University of WisconsinMadison, with a minor in Life Sciences Communication. She holds a M.S. in Civil and Environmental Engineering from UW-Madison and a B.A. in Geology from Carleton College. Sarah pursues interdisciplinary research to develop, communicate and integrate water resources management strategies for improved resilience of communities vulnerable to climate variability. Sarah is the policy engagement chair for the Catalysts for Science Policy. She is passionate about increasing scientific literacy and fostering science-based policy to address critical societal challenges.

Laura Borth is a Ph.D. student in the Department of Nutritional Sciences at University of WisconsinMadison, with a Life Sciences Communication minor. She holds a Registered Dietitian credential and a B.S. in Dietetics and German from University of Wisconsin-Stevens Point. She studies how high fat diets like the ketogenic and Atkins diet can treat Fragile X Syndrome, a genetic disease. Laura is an active member and former operations director of Catalysts for Science Policy. She is passionate about communicating nutrition 
and science to the public and working with lawmakers and nonprofits to advance effective science-based policy.

Jennifer Bratburd is currently a Missouri Science \& Technology Policy Fellow. She holds a Ph.D. in the Microbiology Doctoral Training Program at University of Wisconsin-Madison and a B.S. in Microbiology from University of California, Berkeley. She studies how symbiotic bacteria protect their hosts from infectious disease. Jennifer is the former policy engagement chair for Catalysts for Science Policy and environmental policy intern for Clean Wisconsin.

Marie Fiori is a Ph.D. candidate in the Department of Chemistry at the University of Wisconsin-Madison. She holds a B.A. in Chemistry from Kalamazoo College. Marie studies organic glasses produced by vapordeposition, similar to those used in OLED devices. She is one of the Co-Presidents of Catalysts for Science Policy. As a member of the National Science Policy Network's Diversity, Equity, and Inclusion Committee, she helps to plan virtual panels to amplify Black and Brown voices and to advocate for equitable science policy.

\section{Acknowledgements}

The authors would like to thank the members of Catalysts for Science Policy (CaSP), a graduate and postdoc led science policy group, at University of Wisconsin for their edits during the development of the memo and editor Ben Isaacoff for his feedback during the revision. 